
\title{
\& Research Square \\ Blocking heat shock protein reduces signs of chronic myeloid leukemia
}

\author{
Yuhang Peng
}

Zhenglan Huang

Fangzhu Zhou

Teng Wang

Ke Mou

Wenli Feng

\section{Video Byte}

Keywords: chronic myeloid leukemia, CML, nuclear localization, Bcr-Abl, HSP90AB1, coiled-coil domain, leukemia, cancer, cancer treatment, heat shock protein, Cell Communication and Signaling

Posted Date: October 14th, 2021

DOI: https://doi.org/10.21203/rs.3.rs-969324/v1

License: () (1) This work is licensed under a Creative Commons Attribution 4.0 International License. Read Full License 


\section{Abstract}

Chronic myeloid leukemia, or CML, is a rare, slow-growing cancer of the bone marrow. It's caused by the protein Bcr-Abl, which builds up and causes cells to grow and divide out of control. Now, researchers have identified one of Bcr-Abl's close molecular partners and figured out how it might be forced to abandon Bcr-Abl and stop its deadly buildup. Experiments revealed that Bcr-Abl interacts with the heat shock protein HSP90AB1. HSP90AB1 supports Bcr-Abl's rampant and deadly buildup in cells by blocking its entry into the nucleus. By deactivating HSP90AB1 in cultured cells with the antibiotic tanespimycin (17AAG), the researchers discovered that they could lock Bcr-Abl in the nucleus, reducing the spread of $\mathrm{CML}$ and programming $\mathrm{CML}$ cells for death. While more work is needed to understand how these processes play out in humans, these findings support the development of heat shock protein inhibitors as viable treatments for $\mathrm{CML}$ and other Bcr-Abl-associated malignancies. 